1 Riggs BL, Hodgson SF, O'Fallon WM, Chao EYS, Wahner HW, Muhs JM, e al. Effect of fluoride treatment on the fracture rate in postmenopausa women with osteoporosis. N Engl f Med 1990;322:802-9.

2 Christiansen C, Riis BJ. 178-Estradiol and continuous norethisterone: unique treatment for established osteoporosis in elderly women. $f \mathrm{Clin}$ Endocrinol Metab 1991;71:836-41.

3 Lufkin EG, Hodgson SF, Kotowicz MA, O'Fallon WM, Wahner HW, Riggs BL. The use of transdermal estrogen treatment in osteoporosis. In: Christiansen C, Overgaard K, eds. Osteoporosis 1990. Vol 3. Copenhagen, Denmark: Osteopress Aps, 1990: 1995-8.

4 Storm T, Thamsborg G, Steiniche T, Genant HK, Sørensen OH. Effect of intermittent cyclical etidronate therapy on bone mass and fracture rate in women with postmenopausal osteoporosis. $N$ Engl f Med 1990;322: 1265-71.

5 Watts NB, Harris ST, Genant HK, Wasnich RD, Miller PD, Jackson RD, $e$ al. Intermittent cyclical etidronate treatment of postmenopausal osteoporosis. N Engl f Med 1990;323:73-9.

6 Gruber HE, Ivey JL, Baylink DJ, Matthews M, Nelp WB, Sisom K, et al. Long-term calcitonin therapy in postmenopausal osteoporosis. Metabolism 1984;33:295-303.

Singer FR, Melvin KEW, Mills BG. Acute effects of calcitonin on osteoclasts in man. Clin Endocrinol 1976;5:333-40.

8 Hedlund T, Hulth A, Johnell O. Early effects of parathormone and calcitonin on the number of osteoclasts and on serum calcium in rats. Acta Orthop on the number of os

9 Overgaard K, Riis BJ, Christiansen C, Pødenphant J, Johansen JS. Nasal calcitonin for treatment of established osteoporosis. Clin Endocrinol 1989; calcitonin for

10 Overgaard K, Hansen MA, Nielsen V-AH, Riis BJ, Christiansen C. Discontinuous calcitonin treatment of established osteoporosis - effects of with drawal of treatment. Am F Med 1990;89:1-6.

11 Overgaard K, Christiansen C. Long-term treatment of established osteoporosi with intranasal calcitonin. Calcif Tissue Int 1991;49(suppl):S60-3

12 Overgaard K, Hansen MA, Riis BJ, Christiansen C. Discriminatory ability of bone mass measurements (SPA and DEXA) for fractures in elderly postmenopausal women. Calcif Tissue Int 1992;50:30-5.

13 Altman DG. Randomisation. Essential for reducing bias. BMf 1991;302: $1481-2$.

14 Nilas L, Borg J, Gotfredsen A, Christiansen C. Comparison of single- and dual-photon absorptiometry in postmenopausal bone mineral loss. $f \mathrm{NuCl}$ Med 1985;26:1257-62.

15 Hansen MA, Hassager C, Overgaard K, Marslew U, Riis BJ, Christiansen C. Dual-energy $\mathrm{x}$-ray absorptiometry: a precise method of measuring bone mineral density in the lumbar spine. $\mathcal{N}$ Nucl Med 1990;31:1156-62.

16 Kleerekoper M, Parfitt AM, Ellis BI. Measurement of vertebral fracture rate in osteoporosis. In: Christiansen C, Arnaud CD, Nordin BEC, Parfitt AM Peck WA, Riggs BL, eds. Osteoporosis. Proceedings of the Copenhagen international symposium on osteoporosis. Vol 1. Aalborg, Denmark: Stiftsbogtrykkeri, 1984:103-9.

17 Melton III LJ, Kan SH, Frye MA, Wahner HW, O'Fallon WM, Riggs BL. Epidemiology of vertebral fractures in women. Am J Epidemiol 1989;129: $1000-11$.

18 Matthews JNS, Altman DG, Campbell MJ, Royston P. Analysis of serial measurements in medical research. $B M 7$ 1990;300:230-

19 Melton III LJ. Epidemiology of fractures. In: Riggs BL, Melton III LJ, eds. Osteoporosis. Etiology, diagnosis, and management. New York: Raven Press, 1988:133-54.

20 Hansen MA, Overgaard K, Nielsen V-AH, Jensen GF, Gotfredsen A, Christiansen $\mathrm{C}$. No secular increase in the prevalence of vertebral fractures due to postmenopausal osteoporosis. Osteoporosis International. In press.

21 Melton III LJ, Chao EYS, Lane J. Biomechanical aspects of fractures. In: Riggs BL, Melton III LJ, eds. Osteoporosis. Etiology, diagnosis, and management. New York: Raven Press, 1988:111-31.

22 Overgaard K, Riis BJ, Christiansen C, Hansen MA. Effect of salcatonin given intranasally on early postmenopausal bone loss. BMF 1989;299:477-9.

23 Overgaard K, Hansen MA, Dirksen K-L, Christiansen C. Rectal salmon calcitonin for the treatment of postmenopausal osteoporosis. Calcif Tissue Int. In press.

24 Chesnut III CH, Ivey JL, Gruber HE, Matthews M, Nelp WB, Sisom K, et al. Stanozolol in postmenopausal osteoporosis: therapeutic efficacy and possible mechanisms of action. Metabolism 1983;32:571-80.

25 Nilas L, Godfredsen A, Hadberg A, Christiansen C. Age-related bone loss in women evaluated by the single and dual photon technique. Bone Miner 1988; 4:95-103.

26 Heaney RP. How can we tell if a treatment works? Further thoughts on the randomized controlled trial. Osteoporosis International 1991;1:215-7.

(Accepted 7 fuly 1992)

\section{HIV infection in a cohort of homosexual and bisexual men}

\author{
A J Hunt, P M Davies, T J McManus, \\ P Weatherburn, F C I Hickson, G Christofinis, \\ A P M Coxon, S Sutherland
}

Department of Sociology,

University of Essex,

Colchester

P M Davies, lecturer

A P M Coxon, research

professor

Department of Social

Sciences, South Bank

University, London

SE1 OAA

A J Hunt, research fellow

$P$ Weatherburn, research

fellow

F C I Hickson, research

fellow

\section{Department of}

Genitourinary Medicine,

King's College Hospital,

London

T J McManus, consultant

Dulwich Hospital Public

Health Laboratory

Services, London

$\mathrm{G}$ Christofinis, research

fellow

S Sutherland, consultant

virologist

Correspondence to:

Mr Hunt.

BMF 1992;305:561-2
Epidemiological studies in the United States report rises in unprotected anal intercourse among gay and bisexual men, ${ }^{1}$ after dramatic reductions in the mid1980s there ${ }^{2}$ and in the United Kingdom. ${ }^{3}$ In 1991 rising rates of rectal gonorrhoea among homosexual men attending genitourinary medicine clinics ${ }^{4}$ led to speculation about increasing HIV risk behaviour in the United Kingdom.

This speculation is complicated by the bias in samples of clinic attenders towards more sexually active men but may be clarified by data from samples of non-attenders.

\section{Subjects, methods, and results}

In 1987-8 we interviewed a cohort of 930 homosexual and bisexual men in 10 cities in England and Wales who had been recruited from sources other than genitourinary medicine clinics. Subsequently $77 \%$, $65 \%$, and $50 \%$ were re-interviewed annually. All men were interviewed about current and past sexual behaviour. Respondents in London and South Wales were asked, though not required, to provide a blood sample for testing for HIV-1 antibody; for each year $344,290,240$, and 296, about two thirds of those eligible, did so. The results, with counselling, were available to the men at their specific request. They were linked with behavioural data only for analysis. Ethical committee approval was obtained for all localities at each stage of the study.

The median age of the original cohort was 29 (range 15 to 81 ) years. Full details are given elsewhere. ${ }^{5}$ The proportion of regular clinic attenders was $31 \%$ in 1987-8 and did not vary significantly. The proportion tested before the study began was $41 \%$, rising in 1991 to $54 \%$ of the men interviewed.

The proportion of samples positive for HIV-l antibody was significantly higher in the clinic attenders than non-attenders $\left(15.6 \% \quad v \quad 3.8 \% ; \chi^{2}=11 \cdot 35\right.$, $\mathrm{p}=0.0018$ ).

Unprotected anal intercourse was more common in men in regular than in casual relationships $(19 \% v 4 \%)$. The mean annual number of partners with whom anal intercourse occurred increased from 2.0 in $1987-8$ to 2.7 in 1990-1, and the number of partners increased from 12.3 to $17 \cdot 9(t=2 \cdot 53, p=0 \cdot 011)$. Meanwhile, the proportion reporting oro-anal contact in the month before interview rose from $31 \%$ to $41 \%$ and reporting digital-anal contact from $42 \%$ to $57 \%$.

Seventy three men in the cohort were antibody positive, some of whom subsequently died; 13 do not know their HIV status. Eleven (15\% of all positive) men who were antibody negative in 1987-8 subsequently tested positive. The mean period between the positive result and the last negative result was 11 (range 2 to 24) months. In 10 men we could identify the year of seroconversion: our best estimates are 1987, one man; 1988, two; 1989, two; 1990, three; and 1991, two.

All 11 men reported unprotected anal intercourse and a range of other sexual acts before seroconversion. In five unprotected receptive anal intercourse was the probable mode of transmission. In two men unprotected insertive intercourse was the likely mode, but both had also practised receptive fellatio with orgasm, one with a partner known to be antibody positive and one had also engaged in insertive fisting. In the four other men both unprotected receptive and insertive anal intercourse had occurred.

In eight men, the source of infection was clearly identified as a regular partner four of whom were known to be antibody positive at the time. In only one man was the source clearly traced to a casual partner. Three of the seroconversions were not in regular clinic attenders, nor had the men attended in the year before interview. Four men had not previously been tested. 


\section{Comment}

Although the small numbers make conclusive claims hazardous, these data do not substantiate a large increase in unprotected anal intercourse. One reason may be rises in oro-anal and anal-digital contact which impugn the validity of rectal gonorrhoea as a surrogate marker for HIV risk behaviour.

Almost a fifth of men who tested antibody positive in this study were not clinic attenders. Just under a sixth of positive men became infected after the government campaigns began in 1986-7. Health promotion for gay and bisexual men remains a priority, and initiatives which concentrate on HIV transmission within relationships should be encouraged.
This research was funded by the Medical Research Council and the Department of Health.

1 Adib SM, Joseph JG, Ostrow DG, Tai M, Schwartz SA. Relapse in sexual behavior among homosexual men: a two year follow up from the Chicago MACS/CCS. AIDS 1991:5:757-60.

2 Carne CA, Weller IVD, Johnson AM, Loveday C, Pearce F, Hawkins A, et al. Prevalence of antibodies to human immunodeficiency virus, gonorrhoea rate and changed sexual behaviour in homosexual men in London. Lancel 1987; i:656-8.

3 Stall RD, Coates TJ, Hoff C. Behavioural risk reduction for HIV infection among gay and bisexual men. American Psychologist 1988;43:878-85.

4 Waugh MA. Resurgent gonorrhoea in homosexual men. Lancet 1991;337:375.

5 Davies PM, Hunt AJ, Macourt M, Weatherburn P. A longitudinal study of the sexual behaviour of homosexual males under the impact of AIDS: a final repon submitted to the Department of Health. London: Project Sigma, 1990.

(Accepted 30 June 1992)

\section{Relation of serum sialic acid to lipid concentrations}

\author{
Ichiro Wakabayashi, Kunihiro Sakamoto, \\ Sachiko Yoshimoto, Hidehisa Masui
}

Department of Hygiene,
Hyogo College of
Medicine, Hyogo 663,
Japan
Ichiro Wakabayashi,
assistant professor
Kunihiro Sakamoto,
professor
Sachiko Yoshimoto, research
officer
Hidehisa Masui, research
officer

Correspondence to: Dr Wakabayashi, Department of Hygiene, Hyogo College of Medicine, 1-1 Mukogawa-cho, Nishinomiya, Hyogo 663 Japan.

$B M 7$ 1992; 305:562-3

\section{Subjects, methods, and results}

Sialic acid, a constituent of plasma membrane, is present in most acute phase reactant proteins. A recent epidemiological study showed that mortality from cardiovascular diseases was higher in a population with high concentrations of serum sialic acid. ${ }^{1}$ The increase is suspected to reflect the existence or activity of the atherosclerosis process. We investigated the relation of serum sialic acid to serum lipids, which strongly influence the occurrence and advance of atherosclerosis.

Subjects were 382 men (35-54 years old) participating in a periodic medical health examination at their workplace; the response rate was $98 \%$. Blood was sampled between 9 am and noon after subjects had fasted overnight. Serum lipids (total cholesterol, high density lipoprotein (HDL) cholesterol, and triglyceride) were analysed on an automatic analyser. Serum sialic acid was measured by the enzymatic method. ${ }^{2}$ An atherogenic index was calculated as: atherogenic index $=($ total cholesterol $-\mathrm{HDL}$ cholesterol $) /$ HDL cholesterol

Data are expressed as means $\pm(\mathrm{SE})$. Student's $t$ test was used to compare group means. The values for each serum lipid variable were arranged in ascending order and then the subjects were divided into four groups of approximately equal size. As serum sialic acid concentration is known to increase with age, ${ }^{1}$ multiple regression analysis was performed with serum sialic acid as a target coefficient and the four items of age, serum triglyceride, total cholesterol and HDL cholesterol as explanation coefficients. As the atherogenic index is strongly affected by serum total and HDL cholesterol values, it was not included as an explanation coefficient of the multiple regression analysis. $p$ Values $<0.05$ were defined as significant.

Mean concentrations of serum sialic acid were compared among the fourths of each serum lipid variable (triglyceride, total cholesterol, HDL cholesterol, and atherogenic index). Mean serum sialic acid concentrations in the highest fourth of serum triglyceride, total cholesterol, and atherogenic index were significantly higher than in the other three divisions, and sialic acid concentrations were higher in

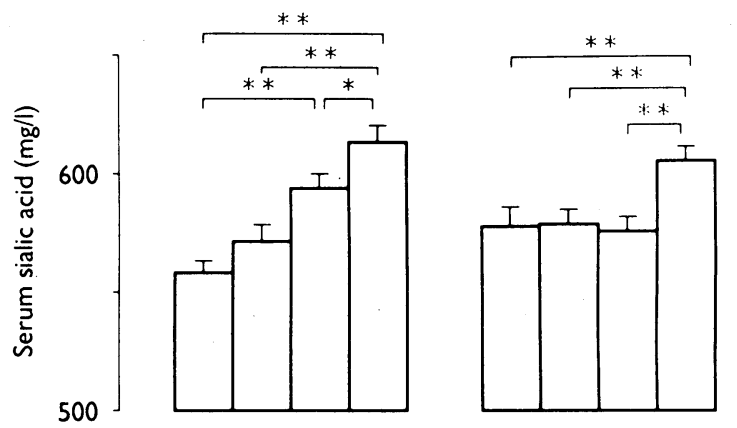

Serum triglyceride

Total cholestero
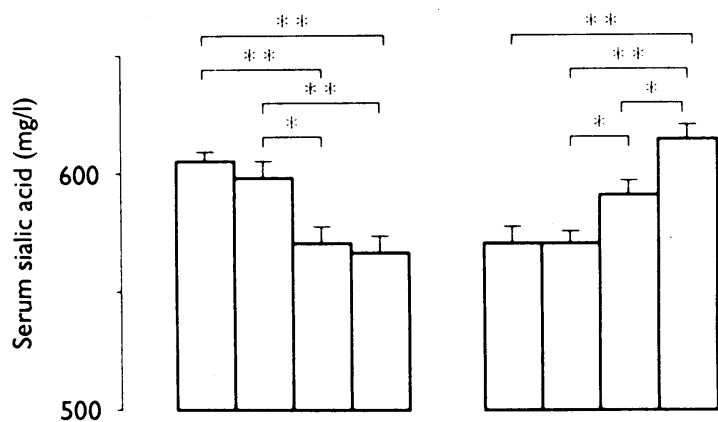

HDL Cholesterol

Atherogenic index

Serum sialic acid concentrations related to serum lipid variables, in fourths. Bars indicate $S E ;{ }^{\star}=p<0.05, \star \star=p<0.01$

each fourth of serum triglyceride and atherogenic index. For HDL cholesterol, however, sialic acid concentrations of the upper two fourths of HDL cholesterol were significantly lower than those of the lower two fourths, and the mean values of serum sialic acid were lower in each higher quartile of HDL cholesterol (figure). Standardised multiple regression coefficients between serum sialic acid and age, HDL cholesterol, triglyceride, and total cholesterol were $0.100(\mathrm{p}<0.05),-0.146(\mathrm{p}<0.01), 0.137(\mathrm{p}<0.05)$, and $0.030(\mathrm{p}>0.05)$, respectively.

\section{Comment}

A slight but significant positive correlation between serum total cholesterol and sialic acid in a large population and a strong positive correlation between serum triglyceride and sialic acid in patients with diabetes mellitus have been reported. ${ }^{13}$ In our study, serum sialic acid concentration was significantly higher 